\title{
Phytoremediation of Lead by Ceratophyllum demersum Lab. Work
}

\author{
Nashmeel Ali Hassan ${ }^{1 *}$ and Sahira H.H. Al-Khalidi ${ }^{2}$ \\ ${ }^{1}$ Directorate General of Baghdad Education, Rasafa third, Iraq \\ ${ }^{2}$ Educational Directorate, Ministry of Education, Diyala, Iraq
}

*Corresponding author

\section{A B S T R A C T}

\section{Keywords \\ C.demersum, Heavy metal, Phytoremediation \\ Article Info \\ Accepted: \\ 16 April 2018 \\ Available Online: \\ 10 May 2018}

This study was done to recognize the capacity of $C$. demersum for different concentrations of lead element in lab aqueous ecosystem. The concentrations of 10, 20 and $30 \mathrm{ppm}$ were used in three replications for each concentration for 30 days. The results showed that the plant can remove $30 \mathrm{ppm}$ of $\mathrm{Pb}$. Significant differences were found in removing capacity by plant for $\mathrm{Pb}$, in all concentrations $10,20,30$ during experiment period. There was accumulation in the stem more than the leaf. The highest removal ratio for $\mathrm{Pb}$ in the stem was $10.25 \mathrm{ppm}, 9.18 \mathrm{ppm}$ in the leaf and the lowest removal ratio was $8.01 \mathrm{ppm}$ in the concentration 30 ppm for 30 days.

\section{Introduction}

Lead $(\mathrm{Pb})$ is a naturally occurring element found in small amounts in the earth's crust, while it has some beneficial uses; Lead a toxic element is harmful to plants, lead moves into and throughout ecosystems. Atmospheric lead is deposited in vegetation, ground and water surfaces (Chen, 2011). The chemical and physical properties of lead and the biogeochemical processes within ecosystems will influence the movement of lead through ecosystems (Sasmas et al., 2015). The metal can affect all components of the environment and can move through the ecosystem until it reaches equilibrium.

Lead can accumulate in the environment, but in certain chemical environments it will be transformed in such a way to increase its solubility (e.g., the formations of lead sulphate in soils). The effects of lead on the ecosystem level are usually seen as a form of stress (Brain, 2002).

Plants on land tend to absorb lead from the soil and remain most of this in their roots. There is some evidence that plant foliage may also take up lead and it is possible that this lead is moved to other parts of the plant) (Cador, 1996). The uptake of lead by the roots of the plant may be reduced calcium and phosphorus to the soil. Some species of plant have the capacity to accumulate high concentrations of lead (Carolyn, 1997).

Lead pollution coats the surface of the leaf and reduces the amount of light reaching it. This 
results in stunting the growth or killing the plants by reducing the rate of photosynthesis, inhibiting respiration, encouraging an elongation of plant cells influencing root development and causing pre-mature aging

Van and Clijsters 2013 suggest that lead can affect population genetics (Phukan et al., 2015). All these effects have been observed in isolated cells or in hydroponically grown plants in solutions of around 1-2 ppm of lead in soil moisture e.g., the lead levels experienced by ecosystems near smelters or roadsides (Mishra, 2008).

Lead is one of the most abundant toxic metals that pose a serious threat to human beings, animals and phytoplanktons. In human, it is absorbed directly into the blood stream and is stored in soft tissues, bones and teeth (95\% in bones and teeth) (Mitchell, 1987).

\section{Materials and Methods}

\section{Collecting and growing of Ceratophyllum demersum}

Ceratophyllum demersum Plant samples were collected from Tigris River in Iraq (Figure 1). Plants were well washed and placed in two glass containers $(40 * 50 * 80) \mathrm{cm}$ filled with water from the same river. After a month period plants put to experimental containers $(10 * 20 * 30) \mathrm{cm}$, their capacity 4L of water.

Care was taken to prevent the decrease in water level by adding the oxygenated water.

\section{Physical and chemical measurements}

Some physical and chemical measurements were done for river water directly as following:

Temperature was measured by water thermometer.
$\mathrm{pH}$ was measured by $\mathrm{pH}$ meter type Milwaukee, Romania

Electrical conductivity and salinity were measured by Conductivity meter type Milwaukee, Romania.

Total dissolved solids (TDS) were measured by TDS meter type Milwaukee, Romania.

\section{Plant acclimatization}

Plants were transferred to laboratory and put in glass container contain $30 \mathrm{~L}$ of distilled water (Figure 1), the laboratory temperature was adjusted to $20 \pm 2 \mathrm{C}^{\circ}$.

10 the plant samples were putting in each container to avoid the crowing.

\section{Preparation of heavy metals concentration}

Heavy metals solutions were prepared by using $0.7996 \mathrm{~g} \quad \mathrm{~Pb}\left(\mathrm{NO}_{3}\right)_{2} \quad(\mathrm{BDH}$, England) dissolved in 1litter of distil water to prepare 1 liter of concentrations 10, 20 and $30, \mathrm{mg} \backslash \mathrm{L}$ of $\mathrm{Pb}$.

\section{Heavy metals measurement}

Leaves and stems left in the sun to dry. 1 gram of dry plants sample was digested by $16 \mathrm{ml}$ of mixture from $\mathrm{HNO}_{3}(64 \%)$ (BDH, England) and $\mathrm{H}_{2} \mathrm{O}_{2}(30 \%)$ (BDH, England) in ratio 6: 2 and the mixture was put in the oven at $120 \mathrm{C}^{\circ}$ for two hours.

After cooling the digested samples, $10 \mathrm{ml}$ of distilled water were added; the mixture was filtered through filter papers $(0.45 \mu \mathrm{M}$, Whatman) and diluted to $50 \mathrm{ml}$ (Senila et al., 2011). Flame Atomic Absorption

Spectrophotometer type (VGP 2010 Buck, England) was used to measure the heavy metal concentrations in plant samples. 


\section{Results and Discussion}

The results of statistical analysis and examine the least significant difference LSD At the probabilistic level $\mathrm{P}<0.05$ to a significant effect for incoming factors in the study Duration of experience and concentration in the level of soluble lead absorption in water of plant showed from the results there were significant difference between (time and concentration) in the absorption capacity of the plant for lead and the effect of time was clear in absorption index, we note increased lead adsorption in a plant as the experiment progresses showed the results of experiment no significant differences at the probabilistic level $\mathrm{P}<0.05$ in increase the absorption of lead element in first day compared to the period of absorption 30 days, refers that to the maximum efficiency of absorption to pollutants present in water, including lead thirty days, showed the results of statistical analysis and examine the least significant difference LSD $\mathrm{P}<0.05$ to significant difference for concentration $(10,20,30) \mathrm{ppm}$ in the study in the a mount of absorption and accumulate lead element from $C$. demersum plant, and when comparing between the concentration $(10,20) \mathrm{ppm}$ no significant different the least difference at the probabilistic level $\mathrm{P}<0.05$ as shown in the table 1.

The results are consistent with the study (Vahati and Khara, 2012) which he did Hydrocotyleranoncloids, $C$. demersum to they can concentrate to determine their ability to concentrate lead and Cadmium in their tissues, the results were stem of Cadmium higher ability to absorbed than their leaves (Fig. 1-6).

Table.1 Concentration of lead in root and stem and leaf of Ceratophyllum demersum

\begin{tabular}{|c|c|c|c|c|c|c|}
\hline \multirow{2}{*}{$\begin{array}{c}\text { Time of } \\
\text { Experemental }\end{array}$} & \multirow{2}{*}{$\begin{array}{c}\text { Part of } \\
\text { plant }\end{array}$} & \multicolumn{4}{|c|}{ ppm (Concentrations) } & \multirow[t]{2}{*}{ LSD } \\
\hline & & Control & 10 & 20 & 30 & \\
\hline \multirow{3}{*}{ First day } & Leaf & 0.30 & 0.35 & 1.36 & 2.89 & $0.562 *$ \\
\hline & Stem & 0.42 & 1.06 & 2.48 & 3.01 & $0.478^{*}$ \\
\hline & LSD & $0.25 \mathrm{NS}$ & $0.442 *$ & $0.561 *$ & $0.447 \mathrm{NS}$ & --- \\
\hline \multirow{3}{*}{ Fifth day } & Leaf & 0.08 & 1.36 & 3.07 & 5.23 & $0.803^{*}$ \\
\hline & Stem & 0.29 & 2.21 & 4.19 & 7.17 & $1.034 *$ \\
\hline & LSD & $0.094 *$ & $0.352 *$ & $0.469 *$ & $0.994 *$ & --- \\
\hline \multirow{3}{*}{ Tenth day } & Leaf & 0.27 & 2.08 & 5.42 & 6.77 & * 0.885 \\
\hline & Stem & 0.31 & 3.10 & 6.39 & 8.36 & * 1.338 \\
\hline & LSD & 0.193NS & $* 0.507$ & * 0.675 & * 1.028 & --- \\
\hline \multirow{3}{*}{ Fifteenth day } & Leaf & 0.28 & 2.68 & 5.85 & 8.53 & * 1.096 \\
\hline & Stem & 0.30 & 4.43 & 7.29 & 11.67 & * 1.463 \\
\hline & LSD & $0.183 N S$ & * 0.609 & * 0.778 & * 1.068 & --- \\
\hline \multirow{3}{*}{ Thirteeth day } & Leaf & 0.16 & 3.15 & 7.23 & 11.39 & * 2.054 \\
\hline & Stem & 0.23 & 5.07 & 9.44 & 13.69 & * 2.456 \\
\hline & LSD & 0.189NS & * 0.791 & * 0.769 & * 0.882 & --- \\
\hline \multicolumn{3}{|c|}{ NS: Not significant } & \multicolumn{4}{|c|}{$* \mathbf{P}<0.05$} \\
\hline
\end{tabular}


Fig.1 Iraq map showing the Tigris River

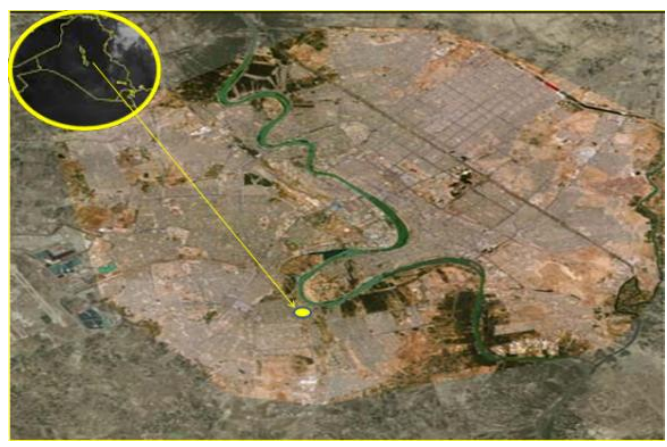

Fig.2 Concentrations (ppm) of lead in plant tissues after first day of experiment period

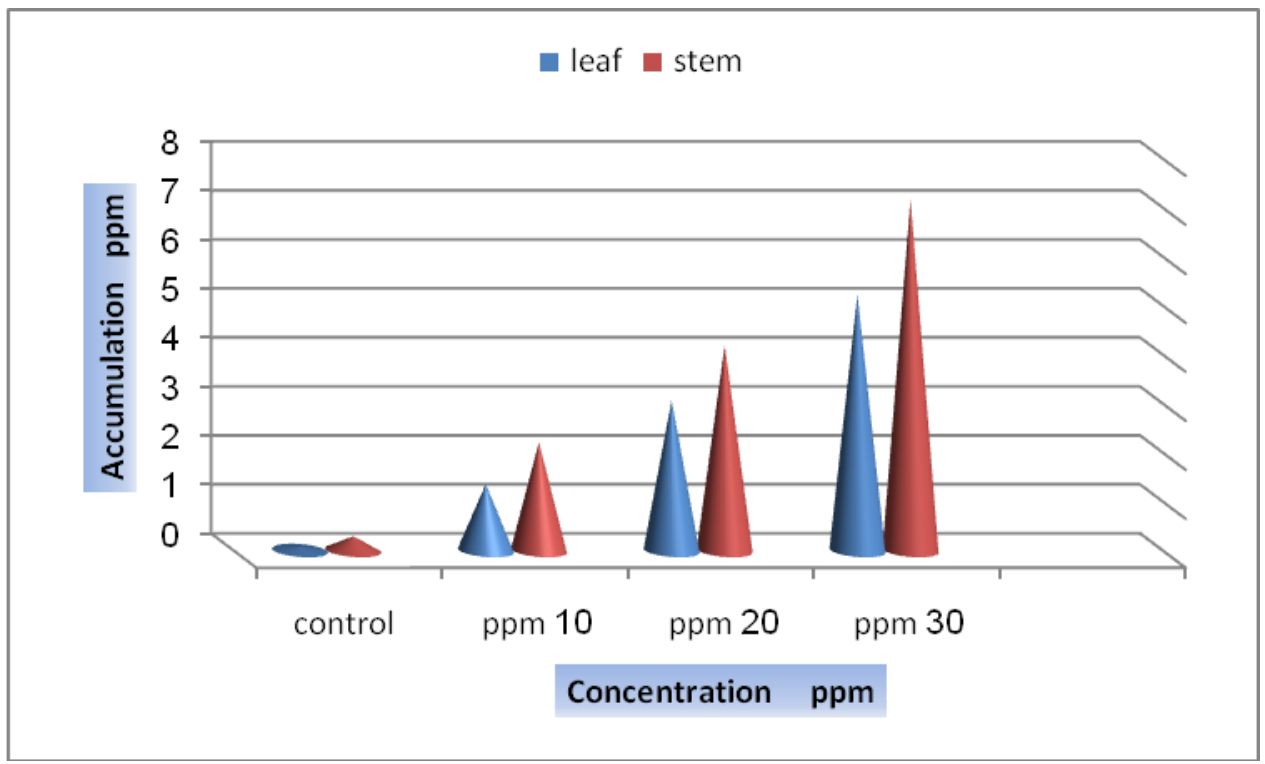

Fig.3 Concentrations (ppm) of lead in plant tissues, after 5 days of experiment period

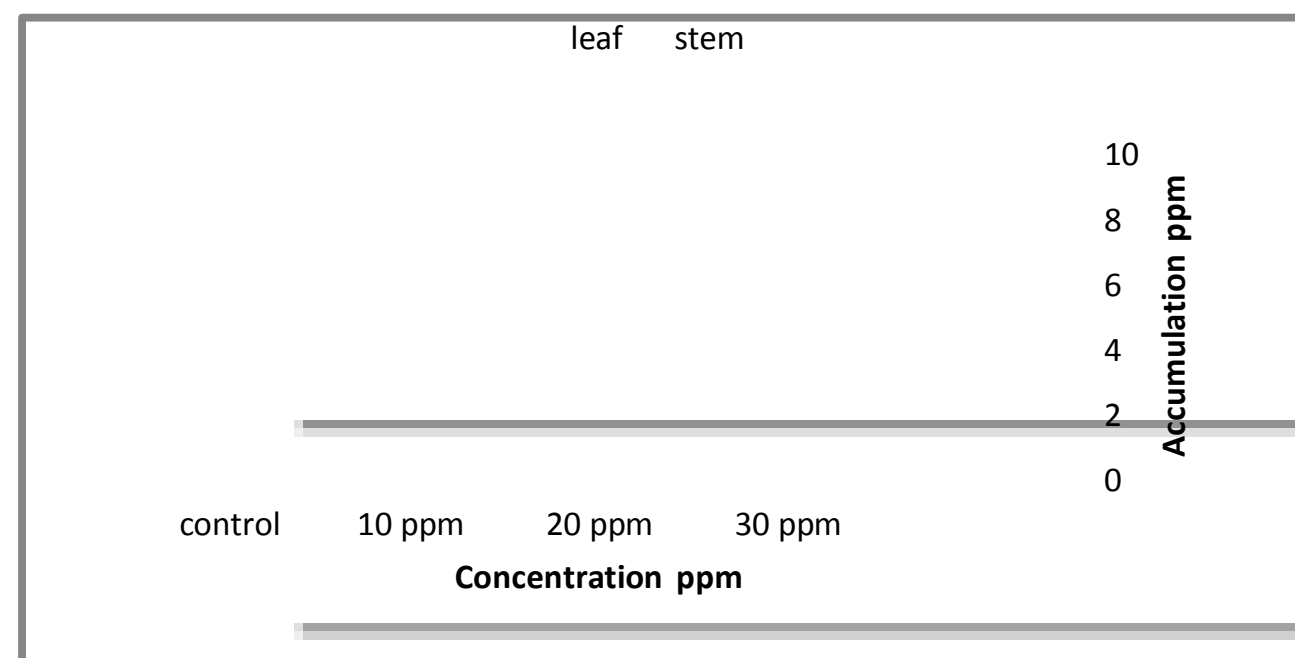


Fig.4 Concentrations (ppm) of lead in plant tissues, after 10 days of experiment period

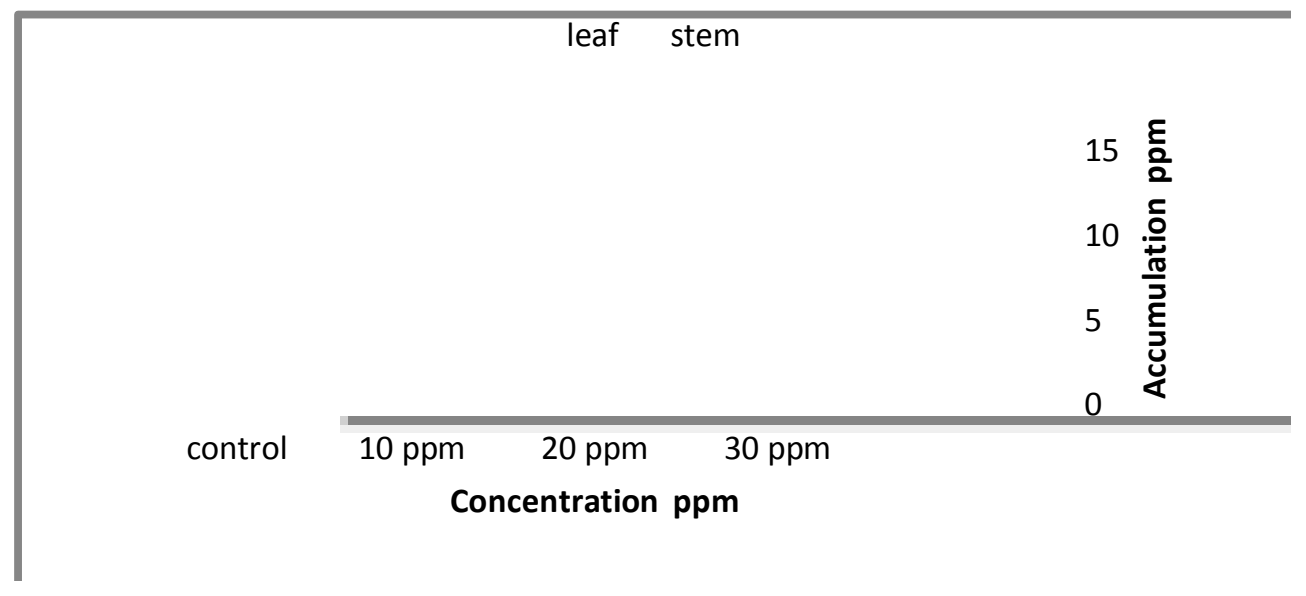

Fig.5 Concentrations (ppm) of lead in plant tissues, after 15 days of experiment period

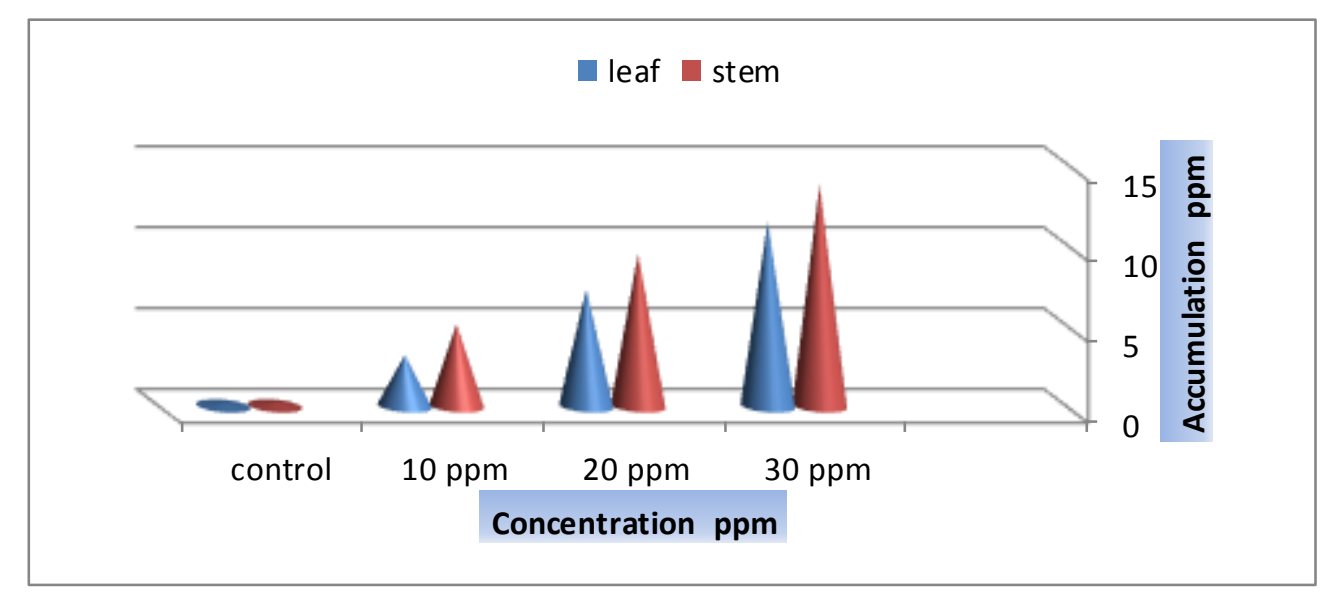

Fig.6 Concentration (ppm) of lead in in plant tissues, after 30 days of experiment period

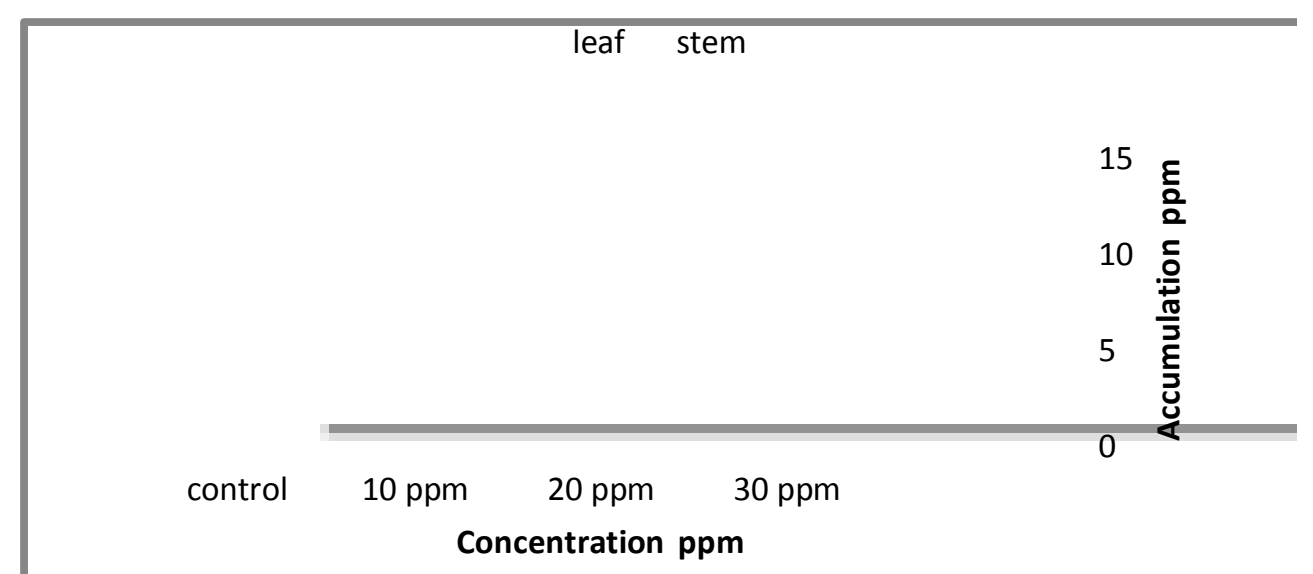


The effect of the time of the experiment and the concentration of the plant element in the bioconcentration factor were observed. The highest values of the bioconcentration factor in the leaves of the sham plan were 2.85. At 20 days after 30 days and the lowest 0.12 concentration at 10 days after 10 days. In the legs, the concentration coefficient was higher than the leaves. The highest was 1.79 at the $30^{\text {th }}$ concentration on the $30^{\text {th }}$ day of the experiment and the lowest concentration was 0.08 at the concentration of 10 After 24 hours of experiment, the study showed a change in the ability of plants to tolerate the elements. The plant began to wither during the days of the experiment. The results also showed the high capacity of the sham plan plant to remove, especially when the concentration increased in the water medium to $30 \mathrm{ppm}$.

These results coincide with Syriyani et al., (2014) during their laboratory experiment by exposing the shamplan plant to concentrations $(10,20,30,50)$ parts per million of cadmium, $\mathrm{Cd}$ and $\mathrm{CO}$ iron and $\mathrm{Fe}$ for five weeks. And also consistent with Kamel (2013). In the study of the susceptibility of six water plants and their ability to withstand six types of heavy elements $\mathrm{Cd}, \mathrm{Co}, \mathrm{Cu}, \mathrm{Ni}, \mathrm{Pb}, \mathrm{Zn}$, it was found that the biological concentration coefficient of the elements follows the following compatibility $\mathrm{Pb}>\mathrm{Cd}>\mathrm{Cu}>\mathrm{Ni}>$ $\mathrm{Co}>\mathrm{Zn}$.

\section{References}

Brain, O.E, (2002) Sources of Lead. J of Lead Advisory Service, 1(1): 53-58.

Çador, Isabel Ca., Vale, Carlos and Catarino, Fernando. (1996). "Accumulation of Zn, $\mathrm{Pb}, \mathrm{Cu}, \mathrm{Cr}$ and $\mathrm{Ni}$ in Sediments between Roots of the Tagus Estuary Salt Marshes, Portugal". 42(3): 393-403. [Abstract].
Carolyn, K., (1997) Lead Contamination in our Environment, Yale-New Haven Institute. Vol 18:p15-18.

Chen, K., W. Yu, X. Ma, K. Yao, and Q. Jiang, (2011). The association between drinking water source and colorectal cancer incidence in Jiashan County of China: a prospective cohort study. Eur. J. Public. Health. 15: $652-656$.

Kamel A. K. (2013) Phytoremediation Potentiality of Aquatic Macrophytes in Heavy Metal Contaminated Water of El-Temsah Lake, Ismailia, Egypt Middle-East Journal of Scientific Research 14 (12): 1555-1568.

Mishra, S., S. Sivastava, R.D. Ttipathy. Concurrent removal and accumulation of heavy metals by three aquatic macrophytes. Bioresource Technology, 99: 7091-7097, 2008.

Mitchell, W.L, (1987) Lead toxicity and reproduction, J.Occop. Med. London. 18: $15-18$.

Phukan P., Phukan R. and S.N. Phukan Heavy metal uptake capacity of Hydrillaverticillata: A commonly available Aquatic Plant International Research Journal of Environment Sciences. Vol. 4(3), 35-40, March (2015).

Sasmaz M, Topal EIA, Obek E, Sasmaz A (2015) The potential of Lemna gibba L. and Lemna minor $\mathrm{L}$. to remove $\mathrm{Cu}, \mathrm{Pb}$, $\mathrm{Zn}$, and As in gallery water in a mining area in Keban, Turkey. J Environ Manag 163:246-253.

Senila, M., Levei, E., Miclean, M., Senila, L., Stefanescn, L., Marginean, S., Ozunu, A., Roman, C. (2011). Influence of pollution level on heavy metals mobility in soil from NW Romania, Environ. Eng. Manag. J., 10: 59-64

Syriyani, A.W., Otomo, K., Sharmin, S.G (2014) A comparative to phytoremediation of heavy metals by 
two aquatic plants, Journal of Applied Science \& Technology, 3(2): 289-306.

Vahati, V and Khara, A., (2012). Heavy metals in plants: phytoremediation: Plants used to remediate heavy metal pollution. Agri. Biol. J. Am. V. 1(1): 40-46.

Van A. F, Clijsters H (2013) Effects of metal on enzyme activity in plants. Plant Cell Environ. 13: 195-206.

\section{How to cite this article:}

Nashmeel Ali Hassan and Sahira H.H. Al-Khalidi. 2018. Phytoremediation of Lead by Ceratophyllum demersum Lab. Work. Int.J.Curr.Microbiol.App.Sci. 7(05): 2002-2008. doi: https://doi.org/10.20546/ijcmas.2018.705.235 